\title{
ARTICLES
}

\section{CONSIDERING MAALAT AS AN APPROACH TO APPLYING MASLAHAH IN REALITY}

\author{
Muhammad Shahrul Ifwat bin Ishak*
}

\begin{abstract}
Maalat (consequences of an action) was suggested by al-Shatibi as a principle to engage with situations where the outcomes of Islamic rules are not in line with their objectives. While rules in Islam are revealed for the sake of maslahah (well-being), in some situations implementing them might not achieve this element, maybe even militating against it. Through maalat, al-Shatibi suggested providing exceptions in those situations, involving either the banning of a permitted action or the toleration of a prohibited action. However, without a proper understanding of this principle, its application could be misunderstood as a way to justify amending a rule in the name of maslahah. This might eventually endanger the integrity of the Islamic rules. In this regard, this paper aims to analyse al-Shatibi's conception of maalat and identify the fundamentals behind this principle. The findings reveal that the principle of maalat must be applied under the disciplines of $i j t i h a d$ (reasoning) and maqasid al-Shariah (objectives of Islamic law), and with reference to an accurate understanding of reality, thereby ensuring its application is in line with Islamic principles.
\end{abstract}

Keywords: Maalat, Maslahah, Maqasid al-Shariah, Ijtihad, Al-Shatibi .

\section{Introduction}

It is undeniable that the significant contribution of al-Shatibi on maqasid alShariah (objectives of Islamic law) makes him well known as the father of this subject, even though an earlier group of scholars, including al-Juwayni, alGhazali and Izz Abd al-Salam, had already mentioned this concept in their work. ${ }^{1}$ Through his book al-Muwafaqat, al-Shatibi reformed a few elements of maqasid al-shariah, chiefly by considering it as the foundation of rules instead of spiritual wisdom, as written in previous literature. ${ }^{2}$ Moreover, al-Shatibi presented maslahah (well-being) as a practical concept, by establishing its principles and clarifying its relationship with other topics in Islamic jurisprudence. ${ }^{3}$ 
One of al-Shatibi's contributions was to introduce the topic of maalat (consequences of actions). This idea has since been developed as a principle to ensure that the outcomes of implementing Islamic rules are in line with their original maslahah. In cases where they are unable to achieve their maslahah, this principle is applied to provide exceptions banning a permitted action that could lead to mafsadah (harm) or allowing a prohibited action that could lead to more mafsadah were it totally banned. ${ }^{4}$ Both approaches are important to ensure the applicability of Islamic practices, regardless of any change in time and place.

Nevertheless, neither prior to nor after al-Shatibi was this topic discussed by classical Muslim scholarship. In fact, this absence was probably a factor in the creation of al-Shatibi's book. According to al-Darraz, al-Shatibi attempted to oppose a certain reality of his time: so-called jumud (rigidity), when intellectual efforts focus on continuous explanations of previous works based on each madhhab (school of thought). Al-Darraz also claimed al-Shatibi's work was difficult to understand during the latter's own time, since he mixed various disciplines in one topic, with a lack of explanation. ${ }^{5}$

Al-Hussin has identified two factors which explain why al-Shatibi's ideas on maalat did not receive much attention among scholars, particularly from the usuliyyin (experts in usul al-figh). Firstly, usul al-fiqh (the methodologies of Islamic jurisprudence) does not mention maqasid al-shariah, including the concept of maalat. Secondly, even though classical scholars did not mention maalat in their works, they practised the substance of this principle through various other methods, such as maslahah mursalah (unspecific maslahah), dharai (blocking the means, also known as sad al-dharai), and istihsan (considering something better), without therefore any need to merge them into a single principle. ${ }^{6}$ Thus, it can be concluded that al-Shatibi's application of maalat constituted an innovation in the application of Islamic rules as many scholars, particularly the usuliyyin, preferred the traditional approach.

However, in modern times maqasid al-Shariah has been written about as an independent subject. As a consequence, the principle of maalat has received attention among modern scholars. Al-Qardawi points out that maalat is considered one of 'the new fiqhs' that supports the resurgence of Islam in the twentieth century. It is argued that this principle, alongside fiqh al-maqasid (understanding the objectives of Islamic law), fiqh al-muwazanat (understanding equilibrium), figh al-awlawiyat (understanding priority) and fiqh al-ikhtilaf (understanding disagreement), ensure that Islamic practices are moderate. ${ }^{7}$ Meanwhile, in 2012 the European Council for Fatwa and Research (ECFR) issued a resolution projecting maalat as a vital approach to dealing with the issue of Muslim minorities. ${ }^{8}$ 
Based on al-Shatibi's theory, it can be understood that maalat makes a rule in Islam more flexible in terms of its implementation because effort should be expended on realising maslahah in reality (which is the substance of the rule) rather than technical perfection. Nevertheless, the principle of maalat could be misunderstood as a way to justify arbitrarily amending a rule in the name of maslahah, particularly mandatory rules in Islam.

In this regard, this paper aims to study the concept of maalat in Islam. It begins with an analysis of al-Shatibi's theory, since he is the pioneer of this principle. Subsequently, the discussion is followed by an identification of the fundamentals of maalat in order to ensure its application under the discipline of Shari'ah (Islamic law). To indicate the practicality of this principle, two case studies are provided: 1) European women converting to Islam without their husbands, and 2) stipulating the $i b r a$ (rebate) clause in financial agreements.

\section{Al-Shatibi's Theory}

In the chapter on ijtihad (reasoning) in al-Muwafaqat, al-Shatibi introduced his ideas on maalat as follows:

Examination of the maalat of actions is acknowledged and intended according to Shari'ah, whether these actions are lawful or unlawful. Thus, the mujtahid (jurist who practice ijtihad) will only judge an action carried out by individuals, either by action or omission, after examining the consequences of this action: it may be that it is initiated in order to bring about some mașlahah or prevent some mafsadah but it results in the opposite of what was intended, or it may not have been initiated in order to cause mafsadah or prevent mașlahah, but it has resulted in the opposite of this.

If in the first case it was declared to be permissible, the achievement of the maslahah therein might lead to mafsadah equal to or greater than the mașlahah, which would rule out declaration of its permissibility.

Likewise, if in the second case it was declared to be impermissible, the prevention of the mafsadah might lead to equal or greater mafsadah, and it is therefore not valid to declare its impermissibility. ${ }^{9}$

Through the principle of maalat, al-Shatibi explained that implementation of Islamic rules should be considered alongside their actual outcomes, since the latter will affect the former. In other words, achieving maslahah and avoiding mafsadah must be realised through implementation of Islamic rules. In dealing 
with an unexpected situation where the outcome of Islamic rulings go against their objectives, al-Shatibi suggested introducing an exception. In cases where a permissible practice originally intended to bring maslahah may instead lead to mafsadah, he suggested banning it, whilst for a prohibited action originally believed to cause mafsadah but demonstrated to do otherwise in specific circumstances, he recommended allowing it. ${ }^{10}$

Al-Shatibi claimed that maalat is recognised in Islam and developed general and specific justifications for it. Generally, he argued that obligations in Islam aim to bring only maslahah for humans in this life and the hereafter, thereby justifying maalat when such an obligation proves harmful. Also, it is undeniable that some actions could be exercised against their objectives, making it necessary to analyse them carefully. ${ }^{11}$

With regards to specific justifications, a few verses from the Qur'an are cited by al-Shatibi:

1. O mankind, worship your Lord, who created you and those before you, that you may become righteous (Al-Baqarah, 2:21).

2. O you who have believed, decreed upon you is fasting as it was decreed upon those before you that you may become righteous (Al-Baqarah, $2: 183)$.

3. Jihad is ordained for you though you dislike it, and it may be that you dislike a thing which is good for you and that you like a thing which is bad for you (Al-Baqarah, 2:216).

4. And insult not those whom they (disbelievers) worship besides Allah, lest they insult Allah wrongfully without knowledge (Al-Anam, 6:108)

From the above verses, it is understood that worshiping God and fasting will lead Muslims to piety. Likewise, jihad, while requiring sacrifices, defends and protects the rights of the people. As for insulting non-Muslims, this is prohibited since it leads to retaliatory insults against Allah.

All these points are taken by al-Shatibi as a foundation for supporting his ideas on the principle of maalat. ${ }^{12}$ In addition, al-Shatibi also identifies several prophetic practices supporting this concept:

1. When the Prophet refused to take any action towards the munafiqin (hypocrites), saying: Let the people not say that Muhammad kills his companions. ${ }^{13}$

2. It was reported that the Prophet changed his mind about re-establishing the shape of the kabah after he realised that newly converted Meccan people might have difficulty accepting this action. ${ }^{14}$ 
3. The Prophet prohibited his companions from trying to stop a Bedouin from urinating in the mosque, saying this would bring harm to the Bedouin and disperse the urine more widely. ${ }^{15}$

Also, al-Shatibi attempted to present maalat as an already established method, arguing that its substance was already applied in various principles in Islamic jurisprudence. Such principles included dharai, which is applied to block something because, ultimately, it leads to mafsadah. For example, hiyal (stratagem) is banned because of potentially negative consequences due to wrong intentions, even though the outward action might appear permissible. In contrast, istihsan allows an unlawful matter in a particular situation because of its positive outcomes. Meanwhile, muraah al-khilaf (considering differences) leads a mujtahid to base his decision on a real situation in order to minimise negative consequences.

\section{The Principles of Maalat and Maslahah}

While some scholars argue that al-Shatibi's work is likely to result in new methods, in fact the main role of maalat is to engage with the application of maslahah in reality. It has been unanimously agreed that rules in Islam are revealed with a specific purpose: to bring maslahah and avoid mafsadah through their implementation. However, since maslahah is a general concept for promoting well-being based on God's revelation, realising this purpose in actuality is not as easy as its theoretical discussion suggests. In other words, the main dilemma is when the outcomes associated with implementing a rule do not achieve the intended maslahah.

Through the principle of maalat, maslahah should be considered from the perspective of consequences of practice. In other words, the maslahah of any rule is no longer relevant if it cannot be achieved in reality. At the same time, a specific maslahah in the application of a rule should be treated as having less priority if it affects general maslahah, which is a more important consideration. Similarly, it is important to determine which mafsadah needs to be taken account of and which maslahah can be sacrificed. ${ }^{16}$ In this regard, the principle of maalat emphasises two aspects: remedy and prevention. ${ }^{17}$

Concerning the former, the mafsadah that are already involved in an issue must be tackled first, to prevent them from becoming worse. ${ }^{18}$ The case of how Imam Malik dealt with a marriage conducted without the permission of a wali (guardian) is a good example of this point. According to his original view, this kind of marriage was void since the permission of a wali is considered a main condition of marriage. However, when an actual case of this situation was presented to him, Imam Malik chose Imam Abu Hanifah's alternative view, 
declaring the marriage valid because he realised that his personal view might cause negative consequences at the dissolution of the marriage, especially pertaining to the children resulting from it. ${ }^{19}$

As for the second aspect, the principle of maalat acts to avoid potential mafsadah from happening. An example of this point is when Ibn Abbas answered the question about repentance for murder in Islam. Through his teachings, Ibn Abbas had admitted that murderers still had a chance of repentance for their crime. However, when a man asked him about the same issue, he replied that the murderer will not be forgiven by God. After being asked by his students about his inconsistent views, he explained: "I suspect that this is a disgruntled man who wants to murder a believer." ${ }^{20}$ It is clear that Ibn Abbas changed his view because of the potential consequences; he was afraid that if he answered 'yes', it might encourage the man to proceed with his intent to kill someone. ${ }^{21}$

\section{The Fundamentals of the Principle of Maalat}

Examining maalat, it can be understood that the main concern of this principle is not its status, but its application with regard to Islamic rules. Since this principle emphasises the achievement of the maslahah of a rule rather any technical aspect, it might be misused as a justification to amend several Islamic rules in the name of maslahah. Thus, the principle of maalat should not be understood as an independent method in ijtihad. Rather, this principle reflects a new manifestation of previous methods which places greater emphasis on considering consequences when implementing Islamic rules. In this regard, since applying the principle of maalat has involved other disciplines such as ijtihad, maqasid alshariah, and understanding reality, those subjects should represent the principle's fundamentals.

\section{The First Fundamental: Ijtihad}

Since al-Shatibi introduced maalat under ijtihad, it must be applied under that discipline. In fact, ijtihad is a juristic process used to transform the Islamic sources into rules and to apply those rules in reality. ${ }^{22}$ While ijtihad plays a significant role in investigating a new or current issue from the perspective of Islam, if misused it could result in rulings that go against Islamic principles. Ijtihad is not a new process, but a means of weighing between different opinions among scholars. ${ }^{23}$

With respect to the principle of maalat, mujtahids need to widen their knowledge by studying various scholarly views, regardless of schools of thought, in order to choose the best one when dealing with reality. If mujtahids realise the negative consequences of a rule when it is implemented, an investigation must 
examine the status of that rule. As a first step, it is necessary to determine whether the rule is based on ijma (consensus) or is a subject of contention among scholars. In general, if a rule is the subject of ijma, its status should not be questioned. This is because ijma puts an end to doubt; when it throws its weight behind a rule, the latter becomes decisive. ${ }^{24}$ However, if practicing that rule leads to negative consequences influenced by the current situation, then its implementation should be reconsidered. For example, the punishment for stealing in Islam is agreed by all scholars, but its implementation needs a conducive situation. Therefore, not surprisingly, the caliph Umar suspended this kind of rule during years of famine, since implementing it would not achieve its maslahah under those circumstances. ${ }^{25}$

If a rule is a subject of contention, the validity and accuracy of its application therefore needs to be analysed. To take another example, it is argued that the combination of two sales in one contract is prohibited according to the hadith: "Whoever makes two sales in one sale, then for them is the lesser value or it is usury." ${ }^{" 26}$ According to some, this hadith is weak, making it contentious. ${ }^{27}$ But, since almost all current Islamic banking products are based on hybrid contracts, making it extremely difficult to create a single contract that is free from interest, it could be argued that this ruling should be ignored today. If not, Islamic banks would not be able to operate as an alternative to conventional ones.

Ultimately, if mujtahids cannot determine which point of view from within the sources is stronger, the principle of maalat could help discriminate between them. For example, there is the matter of stoning on the days of hajj. According to the majority of scholars, this practice must be done after the sun passes its zenith. However, another view allows stoning before that. Both views have their own foundations within Islamic sources. While the second view seems to be unpopular, particularly among classical jurists, it is pragmatic to apply it nowadays due to the consequences of not doing so; with the presence of millions of pilgrims in a small place, it is better to expand the time of stoning for the sake of people's safety. ${ }^{28}$

\section{The Second Fundamental: Maqasid al-Shariah}

Since the principle of maalat aims to ensure that the outcomes of Islamic rules are in line with their objectives, maqasid al-shariah should be its main fundamental. This concept can be described as the meanings that are emphasised by God in His rules. ${ }^{29}$ It is therefore an effort to discover the comprehensive objectives of Islam before applying it in reality. In other words, maqasid al-shariah is not considered a new source of Islam, but an approach to harmonise the revelation with reality. Thus, maqasid al-shariah prevents the practices of Islam from being diverted in the name of maslahah, as well as avoiding literal textual approaches. ${ }^{30}$ 
In presenting maqasid al-shariah as a fundamental principle of maalat, it should be understood that the consequences of a practice will be assessed by the extent to which it is in line with the maqasid. Therefore, mastering maqasid al-shariah, its concept and its discipline, should be indispensable for mujtahids before considering maalat. This will help mujtahids when dealing with different verses on various issues because they will have obtained a comprehensive understanding towards those verses. The classical issue of price fixing could be a clear example to illustrate this point. During the Prophetic period, this practice was prohibited; in the tabiin period, however, some scholars, such as al-Laith bin Saad, Rabiah and Yahya bin Main, spoke in favour of it. ${ }^{31}$ Analysing the Prophet's words give a clear picture of why this action was prohibited during his time. When people asked him to intervene in the market by fixing prices to offset a price-hike, the Prophet replied:

Indeed, Allah is the creator, the holder, the open-handed, the provider, the pricer (who fixes prices); and I wish I will meet Allah and nobody demands (complains) of me any act I did against Him, not in blood or property. ${ }^{32}$

It can be understood that the Prophet disagreed with price fixing due to the negative consequences for sellers. At that time, the main factor behind the price rises was a limitation of resources. It would therefore have been unfair to force sellers to limit their outcome. Thus, the maslahah for the sellers at that time was considered more important than the maslahah of society. However, during the tabiin period there was a change in market circumstances; price hikes occurred due to market manipulation. At that time, the maslahah of society was the issue of concern, the maslahah of the sellers being no longer relevant. Therefore, scholars issued a fatwa allowing price fixing based on this change of circumstances. ${ }^{33}$

Additionally, since the principle of maalat engages with the clash between maslahah and mafsadah, it must be considered under the discipline of maqasid alshariah. In other words, maqasid al-shariah provides a guideline for mujtahids to distinguish between maslahah and mafsadah in terms of priority. ${ }^{34}$ For example, spending money to help poor people should be prioritised above going on hajj for a second time; abortion for unmarried women for the sake of a family's dignity must be stopped in order to save the life of the unborn victim; and gambling activities, even if they are benefitting the country's economy, should be banned because they have a negative impact on society. ${ }^{35}$

\section{The Third Fundamental: Understanding Reality}

Understanding reality is the third fundamental of maalat because Islamic rules are implemented in the real world. This element is particularly important for 
obtaining the meaning of Islamic primary sources. In other words, some aspects of the Quran and hadith must be understood based on the context at the time of revelation in order to understand the issues behind them. ${ }^{36}$ For example, the verse:

O you who have believed, do not consume riba (usury), doubled and multiplied, but fear Allah that you may be successful (Ali Imran 3:130).

Without knowing the background to this verse, it might be misunderstood to mean that charging a small amount of interest is permitted. In fact, this verse refers to a specific type of interest that was practised by Arabs at that time, known as riba jahiliyyah (pre-Islamic riba), whereby the amount of a debt would be doubled if the debt was extended. ${ }^{37}$

Mujtahids have to work hard to study current reality, which is always changing and renewing. ${ }^{38}$ Otherwise, the implementation of Islam might cause different outcomes from its intended objectives. In this regard, Ibn Qayyim illustrated the consequences if a mufti (a Muslim scholar entitled to issue a fatwa) does not have a proper understanding of the people's situation:

Understanding people is the main fundamental that needs to be mastered by a Mufti and leader. If they cannot master it, even if they have mastered the whole knowledge of Islamic rules, when it comes to implementation, not surprisingly, their act causes more harm than benefit. ${ }^{39}$

Rejecting fiat money is an example of an inaccurate fatwa that neglects reality. When some scholars argue that only the dinar (Roman Byzantine gold coins) and dirham (Persian silver coins) are recognised in Islam, they fail to perceive the fact that nowadays all countries declare fiat money as their official currency. ${ }^{40}$ In fact, dinars and dirhams were only accepted by the Prophet as a monetary unit because Arab people did not mint their own coins at that time. ${ }^{41}$ Today, this fatwa causes negative consequences because those who possess a lot of fiat money might refuse to pay zakah, claiming that it is not 'real' money. Moreover, charging interest on monetary transactions could be justified because fiat money would not be considered true money, unlike the dinar and dirham. ${ }^{42}$

Based on the above fundamentals, it can be concluded that the principle of maalat develops a balanced approach between ijtihad, maqasid al-shariah, and an understanding of reality in order to assess the implementation of a rule. This requires that mujtahids understand the status of the rule, its objectives and the actual circumstances wherein it will be implemented, since all of these points can significantly influence the outcome of the rule. 


\section{Case Studies}

As the last part of this paper, two cases are presented.

\section{Case Study I: European Women who Convert to Islam without their Husbands}

Many new Muslim converts in Europe are women. This trend has raised an issue: some converted women prefer to stay with their non-Muslim husbands. ${ }^{43}$ This situation is considered under the scope of fiqh al-aqaliyyat (Muslim minorities jurisprudence), which needs special consideration because it deals with a different reality than that found in Muslim-majority countries. In general, the majority of Muslim scholars argue that a non-Muslim marriage must be dissolved if only a woman converts without her husband. However, they have a different opinion in terms of whether this process must be carried out immediately, or whether the marriage is still valid until the end of iddah (the waiting period a divorced woman must go through before they can remarry). ${ }^{44}$

Nevertheless, a number of scholars have developed a different approach. AlQarḍawi, for example, argues that such a marriage can remain valid, as such was the opinion of the caliphs Umar and Ali, as well as al-Zuhri. Al-Qardawi argues that this approach can facilitate the life of the newly-converted woman. ${ }^{45}$ Moreover, several other points need to be considered, such as the fact that the number of women who accept Islam is greater than that of men; that the psychological and emotional impact on women and their family would be very negative; that the costs and difficulties of dissolving the marriage would be high; that it might create a negative image of Islam, which would be blamed for breaking up the family; and the possibility of husbands following their wives' path might be reduced. ${ }^{46}$ In other words, requiring newly converted women to leave their husbands because of differences in faith would bring more mafsadah than maslahah.

While preserving this kind of marriage could be in line with maslahah, there are many further issues that need to be taken into account. For example, the 'new' relationship needs to be clarified in terms of the right of husbands towards wives and vice versa. Moreover, the concept of obedience of wives towards their husbands, as well as Islamic practices such as praying, fasting in Ramadan and halal foods, must not be ignored. At the same time, this fatwa should not be generalised, because in every case the degree of maslahah and mafsadah could be different. A clear guideline on this issue should be provided to ensure that intended maslahah does not turn into unexpected mafsadah. 


\section{Case Study II: Stipulating an Ibra Clause in Islamic Financial Contracts}

In 2003, the Central Bank of Malaysia issued a special regulation that Islamic banks must incorporate an ibra clause into their financing agreements. ${ }^{47} \mathrm{Ibra}$ is the withdrawal of the right to collect a debt. ${ }^{48}$ In contrast to conventional banks, which offer interest-based loans, Islamic banks utilise sale-based contracts, where the price of an item is mentioned as the selling price. Later, to tackle market volatility, a floating rate is introduced, which results in two different prices in a contract: the selling price and the price calculated against the specific rate. ${ }^{49}$ For example, the selling price could be based on a profit rate of $10 \%$, but Islamic banks only require a $6 \%$ profit due to the current financing rate, so the $4 \%$ unclaimed rate is considered ibra. The significant role of $i b r a$ can be seen in the case of early settlement by customers; without ibra, customers need to pay the whole selling price, which is significantly higher.

On one hand, the ibra regulation from the Central Bank of Malaysia seems to be contrary to the original concept of ibra, which should be based on the bank's discretion. In fact, ibra is classed under charitable contracts in Islam, such as hibah (gift). Moreover, other bodies, such as the International Fiqh Academy, have issued a resolution that da wa tajil (reducing the amount for speeding up payment), which is the underlying concept of ibra, is allowed as long as it is not agreed upon in advance. ${ }^{50}$ The different approach adopted by the Central Bank of Malaysia, however, is aimed at protecting the maslahah of customers and Islamic banks. As for customers, ibra protects their rights, particularly in the case of early settlement. Otherwise, they are liable to pay the entire selling price despite no deferment having been given to them to settle their debt. ${ }^{51}$ As for Islamic banks, this decision has improved their image in society, as previously many disputes between them and their customers revolved around the unclear and unfair practising of $i b r a .^{52}$

\section{Conclusion}

This paper aimed to study the principle of maalat as an approach to applying maslahah in reality. In this regard, it began with an analysis of al-Shatibi's work, since he is the pioneer of this principle. According to al-Shatibi, the role of mujtahids is not restricted to finding the justification of a rule from Islamic sources, but also includes ensuring its consequences are in line with its maslahah. In this regard, the implementation of Islamic rules might need to be revised in certain circumstances in order to achieve maslahah and avoid mafsadah. Exploring the Islamic sources, the principle of maalat has strong foundations in the Qur'an and hadith. It also reflects the main substance of various methods of ijtihad, such as dharai, istihsan, preventing hiyal, and muraah al-khilaf. 
According to the principle of maalat, maslahah should be evaluated by considering the consequences of implementation. This principle guides mujtahids in identifying the real maslahah and mafsadah in current issues. It also demonstrates how to engage with issues pragmatically. However, without a proper understanding of this principle, its application could be misunderstood as a way of justifying needlessly amending a rule in the name of maslahah. Thus, the findings of this study reveal that the principle of maalat must be applied under the discipline of ijtihad, maqasid al-shariah and understanding reality, so that maslahah is not misused to justify a practice that is against Shari'ah.

\section{Policy Recommendations}

The paper concludes with the following policy recommendations:

1. Maalat should be considered a main indicator of maslahah in various Islamic practices, such as Islamic finance, Islamic criminal law and Islamic family law. But, maalat should not be used merely to permit or ban something; it should be used to develop pragmatic solutions to ensure that Islamic rules can be implemented gradually.

2. Considering maslahah in reality needs empirical evidence derived from specific studies. Providing exceptions from the general rules in Islam (particularly mandatory rules) in the name of maslahah needs to be carried out with strong evidence.

3. Since dealing with current issues is not easy for mujtahids, it is strongly recommended that a collective ijtihad be established between them and professionals who deal with particular issues. Moreover, because reality is constantly changing, any regulation or fatwa based on maslahah needs to be reviewed after a certain period of implementation, to determine whether the intended maslahah has been successfully achieved or not.

\section{Notes}

* Muhammad Shahrul Ifwat Bin Ishak, is a Ph.D. student in the school of Divinity, History and Philosophy (DHP), University of Aberdeen.

1. Jasser Auda, Maqasid Al-Shariah as Philosophy of Islamic Law: A Systems Approach (London: The International Institute of Islamic Thought, 2007), 13-5.

2. Ibid., 15-9.

3. Hammadi al-Abaidi, Al-Shatibi wa Maqasid al-Shariah (Beirut: Dar al-Qutaibah, 1992), 89.

4. Ibrahim al-Shatibi, Al-Muwafaqat fi Usul al-Shariah (Beirut: Dar al-Kutub al- 
Ilmiyah, 2004), 837.

5. Ibid., 10 .

6. Walid al-Hussin, Itibar Maalat al-Afal wa Atharuha al-Fiqhi (Riyad: Dar alTadmoriyya, 2009), 15.

7. Yusof al-Qardawi, Dirasat fi Fiqh Maqasid al-Shariah baina al-Maqasid alKulliyyah wa al-Nusus al-Juziyyah (Cairo: Dar al-Shuruq, 2006), 25.

8. The European Council for Fatwa and Research, Athar itibar Maalat al-Afal $f i$ Taqrir al-Ahkam wa Tanziluha. Available at https://www.e-cfrorg. (Accessed on: 1 March 2018).

9. Al-Shatibi, Al-Muwafaqat fi Usul al-Shariah, 837.

10. Ibid., 837.

11. Ibid., $837-8$.

12. Ibid., 838 .

13. Muhammad al-Bukhari, Al-Jami al-Sahih (Beirut: Dar al-Arqam bin Abi alArqam, n.d.), 838.

14. Ibid., 334.

15. Ibid., 1293.

16. Nur al-Din Mukhtar al-Khadimi, Al-Ijtihad al-Maqasidi (Beirut: Dar Ibn Hazm, 2010), 264.

17. Al-Zahab, Maalat al-Afal wa Atharuha fi Taghyir al-Ahkam, 78.

18. Ibid.

19. Al-Shatibi, Al-Muwafaqat fi Usul al-Shariah, 543.

20. Muhammad al-Qurtubi, Al-Jami li al-Ahkam al-Qur'an (Riyad: Dar al-Alam alKutub, 2003), 445.

21. Al-Raisuni, Nazoriyyat al-Maqasid inda al-Imam al-Shatibi, (Cairo: Dar alShuruq, 2006), 382.

22. Wurqiah Abd al-Razaq, Dawabit al-Ijtihad al-Tanzili fi Dau al-Kuliyat alMaqasidiyah (Beirut: Dar Lubnan, 2003), 24.

23. Yusof al-Qardawi, Al-Ijtihad fi al-Shariah al-Islamiyyah (Kuwait: Dar al-Qalam, 1996), 75.

24. Mohammad Hashim Kamali, Principles of Islamic Jurisprudence (Cambridge: The Islamic Texts Society Miller's House, 2016), 158.

25. Al-Qurtubi, Al-Jami li al-Ahkam al-Quran, 98.

26. Sulayman Abu Dawud, Sunan Abu Dawud (Beirut: Dar al-Fikr, n.d.), 865.

27. Mohammad Shibir, Al-Muamalat al-Maliah al-Muasiroh fi al-Figh al-Islami (Amman: Dar al-Nafais, 2007), 314.

28. Usamah al-Ashqar, Fauda al-Ifta (Amman: Dar al-Nafais, 2009), 42.

29. Muhammad al-Yubi, Maqasid al-Shariah al-Islamiyyah wa alaqatuha bi alAdillah al-Shariyyah (Riyad: Dar al-Hijrah, 1998), 38

30. Ahmad al-Raisuni, Al-Fikr al-Maqasidi: Qawiduhu wa Fawaiduhu (Rabat: Dar al-Baida, 1999), 93-4.

31. Al-Duri, Al-Ihtikar wa Atharu fi al-Fiqh al-Islami (Beirut: Book publisher, 2011), 242.

32. Muhammad Ibn Majah, Sunan Ibn Majah, trans. Muhammad Taufil Ansari (New Delhi: Kitab Bhavan), 314.

33. Al-Duri, Al-Ihtikar, 245.

34. Al-Raisuni, Al-Fikr al-Maqasidi Qawiduhu wa Fawaiduhu, 68. 
35. Ibid., 16.

36. Al-Shatibi, Al-Muwafaqat fi Usul al-Shariah, 265.

37. Ismail Ibn Kathir, Tafsir al-Quran al-Azim (Beirut: Muassasah al-Risalah alNashirun, 2008), 399.

38. Abd al-Hamid al-Najjar, Fiqh al-Tadayyun Fahman wa Tanzilan (Doha: Wizarah al-Awqaf wa al-Syun al-Islami, 1989), 56.

39. Muhammad Ibn al-Qayyim, Ilam al-Muwaqiin an Rabbi al-Alamin (Cairo: Dar al-Hadith, 2006), 1/167.

40. Muslim scholars who do not recognise fiat money as real money include: Abd al-Qadir Badran, Ahmad al-Husaini, Abd al-Rahman al-Sadi, and Yahya Amal. See Shibir, Al-Muamalat al-Maliah al-Muasiroh fi al-Fiqh al-Islami, 163-4.

41. Ahamed Kameel Mydin Meera and Moussa Larbani, 'Part I: Seigniorage of Fiat Money and the Maqasid Al-Shariah: The Unattainableness of the Maqasid,' Humanomics 22, no. 1 (2006): 17.

42. Yusof al-Qardawi, Al-Fatawa al-Shazah (Cairo: Dar al-Shuruq, 2010), 5960.

43. Richard Peppiatt, 'Women and Islam: The Rise and Rise of the Convert,' Independent.co.uk. Available at: https://www.independent.co.uk/news/uk/homenews/women-islam-the-rise-and-rise-of-the-convert-6258015.html. (Accessed on: 2 June 2017).

44. Al-Majlis al-Urubi li al-Ifta wa al-Buhus, Al-Qararat wa al-Fatawa al-Sadirah an al-Majlis al-Urubi li al-Ifta wa al-Buhus (Beirut: Muassasah al-Rayan alNashirun, 2010).

45. Yusof al-Qardawi, Min Huda al-Islam al-Fatawa al-Muasirah (Cairo: Dar alQalam, 2005), 620-2.

46. Khalid Hanafi, 'Turq al-Kashf an al-Maalat,' Al-Majallah al-Ilmiyyah li alMajlis al-Urubi li al-Ifta wa al-Buhus 19, no. 20 (2013): 58.

47. Peppiatt, 'Women and Islam,' 1.

48. Abdul Hamid Mohamad and Adnan Trakic, 'Application and Development of Ibra in Islamic Banking in Malaysia,' The Law Review 2, no. 4 (2013): 28.

49. Ahcene Lahsasna, Shariah Issues and Resolutions on Contemporary Islamic Banking and Finance (Kuala Lumpur: IBFIM, 2014), 345.

50. The International Islamic Fiqh Academy, 'Qarar Bishani a-Bay Bi Al-Taqsit.' Available at http://www.iifa-aifi.org. (Accessed on: 30 March 2018).

51. Mohamed Fairooz Abdul Khir, 'Bilateral Rebate (Ibra Mutabadal) in Islamic Banking Operation: A Critical Appraisal,' International Journal of Islamic and Middle Eastern Finance and Management 9, no. 3 (2016): 450.

52. Asyraf Wajdi Dusuki, Mohamed Fairooz Abdul Khir, and Marjan Muhammad, Implementasi Ibra dalam Produk Berasaskan Harga Tangguh dalam Sistem Perbankan Islam: Analisis dari Perspektif Operasi Perbankan dan Maqasid Syari'ah (Kuala Lumpur: ISRA, 2010), 54. 